Meta

Journal des traducteurs

Translators' Journal

\title{
Translation of English Fiction and Drama in Modern China: Social Context, Literary Trends, and Impact
}

\section{Shouyi Fan}

Volume 44, numéro 1, mars 1999

Théorie et pratique de la traduction en Chine

The Theory and Practice of Translation in China

URI : https://id.erudit.org/iderudit/002717ar

DOI : https://doi.org/10.7202/002717ar

Aller au sommaire du numéro

Éditeur(s)

Les Presses de l'Université de Montréal

ISSN

0026-0452 (imprimé)

1492-1421 (numérique)

Découvrir la revue

Citer cet article

Fan, S. (1999). Translation of English Fiction and Drama in Modern China: Social Context, Literary Trends, and Impact. Meta, 44(1), 154-177. https://doi.org/10.7202/002717ar

\section{Résumé de l'article}

Dans cet article, organisé selon un cadre chronologique et thématique, nous présentons brièvement les débuts de la traduction de la littérature américaine et britannique en Chine, le contexte social dans lequel cette activité traductionnelle s'est déroulée, les pensées littéraires subséquentes qui ont marqué le travail des écrivains chinois et l'impact social que ces travaux littéraires traduits et les théories littéraires ont produit pendant les diverses périodes littéraires sur les différents courants en Chine. Il faut reconnaître que les textes traduits introduits en Chine ne sont que la pointe de l'iceberg. Nous avons besoin davantage de traductions de qualité pour les lecteurs chinois et de plus de traducteurs d'expérience pour faire le travail. 


\title{
Translation of English Fiction and Drama in Modern China: Social Context, Literary Trends, and Impact
}

\author{
shouyi fan \\ Beijing Foreign Affairs College, \\ Beijing, China
}

\begin{abstract}
RÉSUMÉ
Dans cet article, organisé selon un cadre chronologique et thématique, nous présentons brièvement les débuts de la traduction de la littérature américaine et britannique en Chine, le contexte social dans lequel cette activité traductionnelle s'est déroulée, les pensées littéraires subséquentes qui ont marqué le travail des écrivains chinois et l'impact social que ces travaux littéraires traduits et les théories littéraires ont produit pendant les diverses périodes littéraires sur les différents courants en Chine. II faut reconnaître que les textes traduits introduits en Chine ne sont que la pointe de l'iceberg. Nous avons besoin davantage de traductions de qualité pour les lecteurs chinois et de plus de traducteurs d'expérience pour faire le travail.
\end{abstract}

\begin{abstract}
This article, which is organized along a chronological-thematic framework, will briefly review the early days of translating American and British fiction and drama into Chinese, the social context in which these translations were done, the literary ideas which have affected the work of Chinese writers, and the social impact that translated works of literature and literary theory have had in various periods of literature. The bottom line is that the literary works introduced to China to date represent only the tip of the iceberg. We need more quality translations for Chinese readers and more qualified and experienced translators to complete the job.
\end{abstract}

In the H istory of M odern Literary Thought in China, three waves of literary movement are identified: those of 1898, 1919 and the 1980s.

Each of these literary movements occurred after a major social, ideological struggle; prior to each literary movement, there was a literary trend that would negate some aspects of previous literary theories and achievements, followed by a long ebb in literary activity; and each literary movement was accompanied by an importation of foreign literary works on a massive scale, bringing about a fusion of Chinese and foreign literature, and bringing forth a host of literary theorists, critics, writers and translators. (Ma Liangchun and Zhang Daming 1995: 10)

Another theorist claims that 1949, which is a milestone in the history of China, does not necessarily mark a new era for the literary movement. Rather, the leftist tendency that began in the 1930s continued into the mid-1970s. Therefore, the history of modern literary thought in China ends with the conclusion of the Cultural Revolution, at which point begins the history of contemporary literary thought (Wu 
Zhongjie 1996: 324). These authors agree with each other on the chronological division of literary movements in China, and I more or less agree with them. However, for convenience's sake, I will divide the present article into four sections: mid-19th century-1911, 1912-1949, 1950-1978, and 1979 to the present. I will consider each period in terms of its social context, literary trends, and the impact of translations of British and American fiction and drama on Chinese society.

\section{MID-19th CENTURY TO 1911}

\section{The Early Days of Fiction}

In discussing the early days of fiction writing, Evans (1976: 214) asserts, "The beginning, though it is no beginning, can be made with Sir Philip Sidney (1554-1586) [...], writing The Countess of Pembroke's Arcadia, for the purpose of amusing his friends." If this is the beginning of English fiction, then the beginning of Chinese fiction can be traced back to Romance of the Three Kingdoms, by Luo Guanzhong (ca.1330ca.1400), a late Yuan Dynasty (1280-1368) and Early Ming Dynasty (1368-1644) author. The earliest block-print edition dates back to 1494 (Chinese Department of Nankai University 1979: 73-76). If we take into consideration the 80,000 character story-teller's scenario (1321-1323) which preceded Luo's version, we can safely assume that fiction in China has an even longer history. And if we include legends and notebook stories, the history of China's fiction extends even farther back (Shi Changyu 1994: 13-22). Exchanges of fiction between China and the West began many centuries later, through the efforts of missionary-translators. It is believed that $\mathrm{HaO}$ Qiu Zhuan, (alias Xia Yi Feng Yue Zhuan, or Breeze in the M oonlight) a Qing Dynasty (1644-1911) 18-chapter romance, was the first Chinese novel to be translated into English, sometime around 1750 when the manuscript was discovered by James Wilkinson in Canton. The novel was later edited by Archbishop Thomas Percy and published in 1761 in London ${ }^{1}$ (Zhang Hong 1992: 54-57; Song Bainian 1994: 577578; also Liu Shide 1993: 151). Thus it appears that the translation of a Chinese novel into English preceded the publication of an English novel translated into Chinese by about a century. The reason is simple: Western missionaries came to China not only to preach and teach but also to learn and take. They learned Chinese, and began to try their hand at translating. Chinese translators of English were still being trained for the endeavour.

\section{Early Literary Translation}

Literary translation in China began with the translation of Buddhist classics in the East Han Dynasty (25-211). In these works, holy passages were interspersed with literary episodes to make the esoteric doctrines of Buddhism understandable to the common man. The translation of Buddhist works had an enormous impact on the syntax, lexicon and phonology of the Chinese language and on the style and manner of writing fiction, verse, drama and quyi, an ancient performing folk art (See Liang Qichao 1921; Xia Xiaohong 1992 v. 2: 497-502). During the reign of Qian Long (1736-1795) in the Qing Dynasty, the translation of the Holy Bible also had elements of literary translation (Kong Li 1962: 2-3). ${ }^{2}$ But real literary translation did not begin 
on a large scale until after China's defeat in the Sino-Japanese War of 1894-1895 (See Chen Yugang et al. 1989: 6-7).

It is widely believed that Lin Shu's translation (1898) of La dame aux camélias was the first Western novel made available to Chinese readers. But this is apparently not the case. According to Zou Zhenhuan, a translation of Jonathan Swift's Gulliver's Travels (part one) was published serially in Shen Bao (a Shanghai-based Daily, April 15-18, 1872) under the Chinese title Tan Ying Xiao Lu (Sketches from Overseas), and Washington Irving's Rip Van Winkle appeared four days later in the same paper under the title A Sleep that Lasted 70 Years (Zou Zhenhuan 1996: 66-67). But the first translation of an entire novel was apparently an English novel by an unknown author. In his "Preface" to Xin Xi Xian Tan (Idle Chats from Dawn to D usk), 1927, (John Fryer 1839-1928) the translator claimed that the title and the author of the original work were unknown, that an earlier version of the same novel was published in Ying Huan Suo Ji (M iscellaneous Notes over Sea and Land, 1873), and that this was the earliest translation of a foreign novel ever made (See the General Catalogue for title 1134 on p. 100; Zou Zhenhuan 1996: 66-70; Ma Zuyi 1984: 295). The translation was rendered in conformity with the style of zhanghui novels, with each chapter heading taking the form of a rhymed couplet that gave the gist of the chapter (Guo Yanli 1991: 1512-1513).

\section{The Socio-political Function of Fiction}

\section{As Bonnie M cDougall (1971: 2) observes:}

Classic Chinese literature admits only two purely literary forms, poetry and the essay. In a broader sense, it also includes historical, philosophical and general writing, but it definitely excludes fiction and drama, and most literary theorizing is concerned only with the nature of poetry.

H owever, writing fiction was not a respectable undertaking in the eyes of traditional scholars. Kang Youwei (1858-1927) deplored what he saw in his survey of Shanghai bookstores in 1900. Kang said, not without a touch of bitterness, "Learning of the classics has dwindled, giving way to the practice of composing eight-paragraph, stereotyped essays, which in turn has yielded to the reading of novels" (Kang Youwei 1958; Chen Yugang et al. 1989: 35). Reading novels therefore met with contempt from the literati. Despite his sorrow at the passing of the good old days, however, Kang was astute enough to perceive the educational potential of fiction from a strictly utilitarian point of view,

Some of the people who can read and write may not read the classics, but there are certainly none among them who do not read novels. Therefore, those who cannot be educated in the Six Classics can be made to learn from novels; those who cannot be initiated into official histories can be taught so through reading novels; those who refuse to be enlightened by analects of the Sages can be edified by what the novel professes to teach; and a petty offender who is beyond the punishment of law can be chastened by what lessons he might draw from the novel. (Kang Youwei 1958; see Chen Yugang et al. 1989: 35)

But Liang Qichao (1873-1929) was the one who had the revolutionary foresight to recognize the potential political and social impact foreign literature could have on 
an isolated feudal Chinese society. He started Shi Wu Bao (Current Affairs), a news bulletin, in Shanghai in 1896, and reserved space in it for the publication of fictional writings. In his "Preface" to The Translation and Publication of Political Novels, 1898, Liang explicitly stated his purpose in publishing translations of Western fiction: "Fictional writings which are written by renowned authors of foreign countries and are likely to have some bearing on the current situation of China shall be translated and published one by one" (Chen Yugang et al. 1989: 7; italics are mine). Liang believed that works of fiction would serve to inculcate the populace, and that "the publication of political novels should take the largest share of the credit" for the progress made in countries like the USA, the UK, Germany, France, Austria, Italy and Japan (Liang Qichao 1898; see Chen Yugang et al. 1989: 42). This "Preface" by Liang Qichao was regarded as an important proclamation, as the clarion call that awakened China's intelligentsia. In "Fiction and the Education of the Masses" (1902), Liang Qichao discussed the need to introduce new fiction to China to counterbalance the negative influence that certain Chinese novels were exerting on the masses. Liang pointed out in very lucid terms that:

To educate the people of a nation, to reshape their moral behaviour, we must have new fiction; to reform religion and politics, we must have new fiction; to change their customs and let them learn new crafts, we must have new fiction; to remould their ideology and their character, we must have new fiction. Why so? Fiction has an inconceivable bearing on people's conduct.

Therefore, he concluded,

To bring about a reform in the education of the people, we must begin with making a revolution with respect to the publication of fiction; and to remould our people, we must begin with having new fiction. (Liang Qichao 1902; see Xia Xiaohong 1992: v. 2: 3-8)

This article by Liang Qichao did much to encourage aspiring practitioners of translation in China.

The power of fiction was soon felt as Looking Backward, 2000-1887, by Utopian socialist Edward Bellamy (1850-1898), was translated into Chinese by Timothy Richard and published in Wan Guo Gong Bao (Chinese Globe M agazine), a very influential weekly edited by Young J. Allen, between December 1891 and April 1892, and was then published as a book with the Chinese title The Centennial Sleep (Bai Nian Yi Jiao) in 1894. The book describes the great changes that took place during an American's 113-year-long sleep. The novel's publication immediately caught the attention of China's reformists, and even Emperor Guang Xu (reign 1875-1908) had it on his list of Western books to be ordered in 1898. The scenes of a halcyon, affluent and orderly society depicted in the book were in seeming accord with the ideal of "a World of Great Harmony," held by China's intellectuals. In Kang Youwei's 10-volume Da Tong Shu, or Book of Great Harmony, which was completed in 1902 but only published by his disciples seven years after his death, the influence of Bellamy's novel is apparent in both organization and content. Kang acknowledged Bellamy's influence on his writing, saying that "The Centennial Sleep by the American author is a shadow of my Da Tong Shu" (Kang Youwei 1985: 31; see also Xiong Yuezhi 1994: 413). Zeng Guofan (1811-1872), Governor of Zhi Li Province, encouraged the teaching of Western writings, and Emperor Guang Xu also studied Western books. Zhang Zhidong (1837- 
1909), Governor of various provinces, and Li Hongzhang (1823-1901), Governor of Zhi Li Province, gave generous donations to Guang Xue Hui and other translator training schools to support their programmes. The influence of Western writing and thought spread from scholars to common people through the proliferation of novels (Xue Weize, Catalogue of Eastern and Western Works; see Xiong Yuezhi 1994: 12-13).

Between 1860 and 1900, about 555 works by Western authors were published, not including religious works. Of this number, 123 (22\%) were works of philosophy and social science, including some literary works (Xue Weize, Catalogue of Eastern and Western Works; see Xiong Yuezhi 1994: 11-12). "The Classified Catalogue of Newly Arrived Books Collected by the Han Fen Lou Library" listed some 400 titles during the years between the O pium War in 1840 and the 1911 Revolution (see Chen Yugang et al. 1989: 23). But another estimate sets the actual number of translated foreign works of fiction at more than 600 titles between 1875 and 1911, amounting to two thirds of all translated works (Ah Ying 1957: 65-178; Chen Yugang et al. 1989: 7). ${ }^{3}$ The translations ranged from political, educational, detective, and sci-tech novels to prose, poetry, and drama (see Chen Yugang et al. 1989: 24; also Guo Yanli 1991: 15131516). The fiction titles available in translation included Robinson Crusoe, Gulliver's Travels, Ivanhoe, Hard Times, Tess of the D'U bervilles, Jane Eyre, Sherlock Holmes' Stories, Hamlet, School for Scandal, M an and Superman, The Devil's Disciple, Uncle Tom's Cabin, The M an that Corrupted Hadleyburg, The Call of the Wild, The Scarlet Letter, and The Great Earth, to name but a few.

Liang Qichao, Yan Fu (1854-1921), Lin Shu (1852-1924), as well as Ma Junwu (1882-1939), Wu Guangjian (1860-1943), Zhou Guisheng (1862-1926) and others were all active in the translation arena prior to the 1911 revolution. Many reform activists included translations in the newspapers they published, e.g. Qing Yi Bao (The Disinterested Critic, ${ }^{4}$ Shi Wu Bao (Current Affairs), Qiang Xue Bao (Enhancing Learning), Zhong Wai Jian Wen (Chinese and Foreign News et al. 1989: 42). And just as Liang Qichao expected, the influx of Western novels hastened the birth of a new Chinese fiction (Zhu Defa 1986: 393-395).

\section{Lin Shu's Translations}

The boom in translation activities of this period was the outcome of a painful recognition, on the part of China's intelligentsia and some farsighted M andarin officials, of China's weak position against the insatiable Western powers. Lin Shu's lament over China's plight expressed a sentiment common among patriotic Chinese scholars of the time. In his "Preface" to The Betrothed, 1907, Lin remarked that:

Today's China is feckless and declining. It's a great pity that I do not have a wide knowledge, so that I could come up with original works for publication to inspire my countrymen. What I can do now is to translate as many as I can of the stories of Western heroes in order that my people can, by learning from these heroes, get out of their state of lassitude and isolation, and catch up with the strong rival nations. Would that not bring me consolation any the less? (Luo Xinzhang 1984: 175-177)

To inspire his countrymen, Lin Shu translated profusely, one book after another, at prodigious speed. Lin Shu wrote explanatory prefaces to many of his translations to prevent readers from missing the intention of his efforts. He said, in the "Preface" to Eric Brighteyes (1904), that: 
the reason that the translation is entitled The Story of an Amourous Cavalier from I celand [back translation of the Chinese title for Eric Brighteyes, 1891] is that it tells of the amorous affairs between a man and a woman, hence part of the title suggests the romantic substance of the novel; however, my true intention is to tell the readers of the valour of the hero [...] The chivalrous trait of the hero is thus emphasized for the purpose of arousing my people from their lethargic sleep and spurring them on to brave deeds. (see Chen Yugang et al. 1989: 70)

The prefaces to other translations by Lin Shu display the same patriotic sentiment. Joan Haste, by $\mathrm{H}$. Rider Haggard, was first translated by Yang Zilin (pseudonym, Pan Xizi) in expurgated form and published by the Wen Ming (Civilization) Press. Lin Shu, with the aid of Wei Yi, had the complete version published by the Commercial Press in 1905. This created quite the "tempest in a tea cup." The passages omitted from Yang's version dealt with the pregnancy of an unmarried girl, something that went against the ethical code of feudal Chinese society. However, the story of Joan Haste struck such a sympathetic cord in the hearts of educated Chinese readers that one commentator went so far as to say that the Chinese revolution was caused by two novels, La dame aux camélias, and Joan Haste (Requoted from Chen Yuan's Xi Ying's Idle Chats, the Crescent Bookstore, 1931: 57; Zou Zhenhuan 1966: 188). Chen Yuan's assertion is, however, just idle patter which we should not take too seriously. But this novel which received little attention in the author's home country certainly appealed to Chinese readers, and for a good reason: it echoed young Chinese people's desire for emancipation as individuals and freedom to choose their own lovers.

Daniel Defoe's Robinson Crusoe (1719) was first translated in abridged form by Shen Zufen in 1898, then re-translated by Lin Shu and Zeng Zonggong. By the end of the 1940s, the novel had been re-translated, abridged, and condensed by nine different translators, and 20 more versions would be crafted in the second half of the century. What appealed to Chinese readers, especially young readers, was Crusoe's sense of adventure, his unyielding spirit in moments of adversity, and his resourcefulness when confronting nature. At a time when many Chinese were content to lead lethargic, pusillanimous lives, Robinson Crusoe's adventuresome spirit stirred up latent rebellious leanings among the younger generation (Zou Zhenhuan 1996: 192-194).

Beatrice, by H. Rider Haggard (1890), was translated into Chinese by Lin Shu in 1906. In his "Preface," Lin talked about the advocacy of feminism in the late 19th century. In Lin's opinion:

the advocacy of feminism presupposes the education of women; the educated woman would weigh the pros and cons in matters concerning her own matrimony, knowing only too well that indiscretion would not bring her any good, and therefore she would refrain from doing anything reckless...

However, Lin also shared with readers his fear that with the publication of the novel,

People would learn of the lasciviousness of the Western customs, and then would talk no more of the education of women, but still regard a woman as being virtuous if she has had no education at all. However, this is not what I want to see. (see Xue Suizhi and Zhang Juncai 1982: 111-112) 
Uncle Tom's Cabin, by Harriet Beecher Stowe, was rendered into Chinese by Lin Shu and his collaborator Wei Yi in 1901. Lin's aim in translating this novel was to let Chinese people know about the plight of African-Americans and their struggle for freedom, and to "bolster their will to defend the Chinese race" (Xue Suizhi and Zhang Juncai 1982: 104). The publication of Uncle Tom's Cabin in Chinese came at a time when the Exclusion Act of California (1882) was in force and Chinese labourers in the United States were suffering a fate similar to the one Blacks had suffered. Readers from all walks of life in China were both shocked and touched. In Ling Shi's review of the novel, he pointed to the fact that

The cal amity is not about to befall our yellow race: the exclusion of Chinese labourers in the U.S. and the maltreatment of Chinese in various countries in the West are already a fact. Their predicament was in no way different from that of the Negroes, but worse than the latter.

He recommended the novel to all readers, saying that

I weep for my yellow people with the tears I shed for the Negroes; I grieve for the present of my yellow people in the same way I lament the past of the Negroes. I wish that every household had a copy of Uncle Tom's Cabin... (Xue Suizhi and Zhang Juncai 1982: 128-130; Zou Zhenhuan 1996: 145-148)

The social impact of Lin Shu's translation of Western literary works on the hitherto isolated society of China was tremendous. The Chinese literati and officialdom had once been ignorant of the Western world, but now began to understand the social progress that had been achieved in these foreign countries (see Zheng Zhenduo, "M r. Lin Qinnan," in The Short Story Monthly, no. 11, vol. 15, 1924; Xue Suizhi and Zhang Juncai 1982: 149-164). Li Huang, a leading member of the China Youth Party, described his impressions of works translated by Lin Shu and Yan Fu, and explained why he wanted to go abroad to seek knowledge (Li Huang, Reminiscences, (Xue Dun Shi Hui Yi Lu), Taiwan Zhuan Ji Wen Xue Publisher, 1973: 11). Chinese scholars began to see that Western authors were equally competent. Later scholar-writers, baptized in the May 4th Movement, were all influenced by Lin's translations- Lu Xu from La dame aux camélias, Guo M oruo (1892-1978) from Joan Haste and Ivanhoe. Zhou Zuoren (1885-1967), Zhu Ziqing (1898-1948), Shen Yanbing (1896-1981), and Qian Zhongshu (1910- ) all recalled reading Lin's translated works (Xiong Yuezhi 1994: 706-707). In a word, many of Lin's translations had tremendous repercussions in China. As far as literary forms are concerned, Lin Shu's translations marked a break away from the traditional style of the zhanghui novel (Zheng Zhenduo 1924; see Xue Suizhi and Zhang Juncai 1982: 152). Lin was adept at using his elegant classic Chinese to translate narrative writings, and as a result his translations were very popular among scholars of the classic tradition (Xue Suizhi and Zhang Juncai 1982: 252; 289-290). So it was Lin Shu, not speaking a word of any foreign language, who became the pioneer of literary translation in modern China (Kong Li 1962; Xue Suizhi and Zhang Juncai 1982: 252; 289-290).

As is clear from the above discussion, translation in the early modern period had the objective of awakening the Chinese people to the imminent danger of subjugation by the Western powers. We can therefore say that it was motivated by a strong "political utilitarianism." While Classic Chinese language was, at first, used to translate the new ideas from the West, these ideas then hastened the decline of Classic 
Chinese and the adoption of the vernacular form. M ost translations from this early period used the "yiyi" or "sense translation" method, due to the discrepancies be tween Classic Chinese and Western languages. The selection of works for translation, especially literary works, was haphazard, and the quality of translation varied a great deal. However, these early translations paved the way for the growth of China's modern literature in general, and fiction and drama in particular, allowing it to keep pace with the progress of literature in other countries (see Ren Fangqiu 1988: 466470).

\section{The Beginnings of Drama}

According to Ifor Evans, "The beginnings of the drama in England are obscure" (1940/1976: 134-152). The Romans introduced plays into England during the period of Roman occupation, but the theatre subsequently departed along with the Romans. It was the church itself that brought drama back to England, as religious rituals came to demand the inclusion of dramatic elements, which developed into liturgical plays around the 13th century. By the following century, these plays were no longer staged inside the church, but took place in the precincts, and the performance of plays thus became a secular affair. In time, new genres of drama were staged, such as biblical plays, miracle plays, and morality plays. During the 16th century, comedies and tragedies modeled on the Latin plays made their appearance. Christopher M arlowe and William Shakespeare were the prime representatives of this period.

In primitive China, dramatic performances were a melange of dance, song, verse and comic dialogue (Zhang Geng and Guo H ancheng 1980: 1-30). Each performance was centred around a theme and had a plot (Mo Shuyi 1994: 14-44). Scholars disagree about when drama reached maturity: the Tang Dynasty, the Song Dynasty or the Yuan Dynasty. However, most scholars agree that by the Song Dynasty drama had become a mature performing art (Mo Shuyi 1994: 10-13). After the Rebellion of An Shi (A.D. 760), performances that had previously been staged for the royal or noble families were opened to the common people, and, after 1068, were moved from temples to tiled halls (Zhang Geng and Guo Hancheng 1980: 31-43). These performances came to be called zaju or "miscellaneous dramatic pieces," and around the 12th century, two schools of drama began to evolve, one based in Shanxi and Hebei provinces, the other in Yongjia or Wenzhou in Fukien province (hence the names of Northern School and Southern School). Guan Hanqing (?1210-?1300) and Wang Shifu (?-?) ${ }^{5}$ were active during this period, predating Marlowe and Shakespeare by more than two centuries.

When discussing the mutual influences of Western drama and Chinese drama, we again find that it was Chinese drama that was first introduced to European stages in the 18th century. The first Chinese drama presented in Europe was Zhao Shi Gu Er, or as Edward Cave rendered it, Chau Shi Ku Eul: the Little Orphan of the Family of Chau. A Chinese Tragedy (1741). It should be noted that it was a French missionary by the name of Joseph Prémare who translated the play into French in Canton in 1731. The title he gave it was L'O rphelin de la M aison de T chao, and it was published in Du Halde's edited Description de l'Empire de la Chine, in 1735. In 1741 three English versions were published in London, translated respectively by Edward Cave, William Hatchett, and John Watts. Voltai re and Goethe, two literary giants of the day, 
adapted the plays, and other versions, either abridged or complete, were staged in later years (Wang Lina 1988: 443-455; Song Bainian 1994: 328-338; Zhang Hong 1992: 51-54; Zhang Geng and Guo Hancheng 1980: 223). In the introductory remarks to his translation, Hatchett commented that the play contains rational elements that no other plays, even the best ones, can exel (Wang Zhiwu 1988: 132-139). Six or seven more Chinese plays were presented before European audiences over the ensuing years. M ore than a century later, China was forced to open her seaports to the Western powers, and foreign nationals formed amateur theatrical troupes to offer entertainment to their fellow countrymen. Two such troupes were founded in Shanghai, using godowns as makeshift stages. In 1866 the two troupes merged into an amateur dramatic club, and a few years later formed the Lanxin (Blue Heart) Theatre (GeYihong 1997: 6-7). In 1899, Shanghai missionary schools put on some European plays, with all the players speaking either English or French (Zhu Shuangyun, A N ew H istory of D rama; see Guo Yanli 1991: 2155). For a time it became fashionable for the schools to put on "current affairs skits" (Ge Yihong 1997: 7-9), which was how the Chinese became familiar with a new type of drama, first known as xinxi (new drama) or wenmingxi (civilized drama), and later called huaju (spoken or dialogue drama) (Gao Wensheng 1990: 365-367).

\section{Huaju as a New Form of Drama}

As the 20th century began, bourgeois revolutionaries in China were preparing to challenge the tottering Qing Court, already under siege by the encroaching Western allies. Liang Qichao, who had already attempted to educate the Chinese populace by initiating revolutions in verse-making, essay-composing and fiction-writing, was a man clearly aware of the ability of propaganda to rouse people to action. The "reform of drama," he held, was to eventually give birth to a new form of drama, called huaju (Guo Yanli 1993: 962-986). In 1902, the very first issue of New People's Magazine published a play by Liang Qichao entitled "Jie Hui Men Zhuan Qi." The play became legendary, and kick-started the drive to reform drama in China. In 1904, Chen Qubing (1874-1933) and Liu Yazi (1887-1958) put out the first issue of the 20th Century Stage, in which they made no attempt to veil their intention to organize a "theatrical revolutionary army" for the realization of the bourgeois revolution. Liu Yazi proudly announced that,

when the people have been greatly enlightened, and the lost territories returned to us, an independent theatre will be built and the bell of freedom sounded for the staging of plays restorating the glory of the past and overthrowing of the babarian court. That would be the moment for us to shout the slogan of Long Live China! And Long Live the 20th Century Stage! (Guo Yanli 1991: 2116)

Chen Duxiu was quick to see the utilitarian function of the modern plays, commenting that "The theatre is a great school for all the people of China, and the players, great teachers for them" ("On Drama"; Guo Yanli 1991: 2116). However, the new drama was not without its shortcomings, and often appeared comical to Chinese audiences. For instance, an actor in a Western suit was given a horse whip to hold in his hand, a stage prop which symbolized "riding a horse" (Ge Yihong 1997: 5). Another time, an English lawyer spoke all his lines in a peculiar percussive manner, 
mangling the phrase, wo-cong-lun-dun-lai, (I-come-from-Lon-don) (Guo Yanli 1991: 2134). In the process of promoting the new drama, a debate arose between the new and old schools. Hu Shi (1917) extolled Greek and European drama, claiming that their dramatic works "were 10 times better than the Yuan Dynasty drama," and that "we should take them as our models." Fu Sinian, in a more moderate tone, suggested Chinese dramatists could learn from the Western tradition (New Youth, no.4, Volume 5; see GeYihong 1997: 39-42). In the drive to promote the new drama, New Youth, New Wave, and other magazines published many translations of European works of drama in 1920, including George Bernard Shaw's M rs. Warren's Profession and Widowers' Houses.

\section{2-1949}

The more than four decades of intellectual effort by the brave forerunners of the bourgeois revolution had paid off. The notion of Western democracy introduced to China by translators had finally taken root in the minds of the populace, and they were prepared to welcome a new system of government operating according to democratic principles. That new system of government was the culmination of the 1911 Revolution led by Dr. Sun Yat-sen, but it failed to bring about changes in political structure that could radically affect the relationship between ruler and ruled, and between capital and labour. The fresh interpretations of democracy and other new ideas that would give impetus to the emerging proletarian revolution led by the Communist Party of China had yet to emerge. The proletarian revolution took nearly 30 years to triumph over the Nationalist government, which disappointed the masses of China with its unbridled official corruption and relentless exploitation of the labouring people. Standing at the forefront of this people's revolution was Chen Duxiu (1879-1942), champion of the May 4th Movement (1919) and one of the Founding Fathers of the Communist Party of China (1921). New Youth magazine (first published in 1915), edited by Chen Duxiu, played a crucial role in disseminating Marxist theories of revolution, informing the public of the progress of workers' movements in the West, and preparing people to fight for a better, more ideal society. Again, translators played an important part in this revolution of unprecedented scale and momentum.

\section{The New Culture Movement}

The May 4th Movement of 1919 ushered in the era of the New Culture Movement. The N ew Youth Society made a notable contribution to the N ew Culture M ovement in the early part of the century. The Literary Association (Shen Yanbing, Zheng Zhenduo 1898-1958, Zhou Zuoren, and others) was formed in 1921, but broke up long before 1932 when The Short Story Monthly ceased to publish. The Creation Society (Guo M oruo, Yu Dafu 1896-1945, Cheng Fangwu 1897-1984, and others) was founded in 1921, but was closed down by the KM T censorship agency in 1929. The Unnamed Society (Lu Xun 1881-1936, Wei Suyuan 1902-1932, Cao Jinghua 18971987, and others), was formed in M ay 1925, but disbanded in 1931 due to differences. The Crescent Society (Hu Shi 1891-1962, Liang Shiqiu 1903-1987, Xu Zhimo 18971931, and others) came into existence in 1923, along with a number of other societies 
devoted to new literature and literary translation. Besides the New Youth magazine (1915), to which Chen Duxiu, Lu Xun, Shen Yanbing, Hu Shi, Zhou Zuoren, Liu Bannong (1891-1934) were all regular contributors, The Short Story M onthly (19101921) was another important place for the publication of works of translation. Cre ation Quarterly was first issued in 1922, but lasted only until the second issue of volume 2. Creation Weekly, first issued in 1923, put out 52 issues altogether. Under the guidance of Lu Xun, Translation, the first magazine devoted entirely to translation, was launched in 1934, but folded in 1936. A wave of Western literary works in translation followed the founding of these literary organizations, with each group focusing on a particular literary school or trend. The works of Sir Walter Scott, Charles Dickens and Katherine M ansfield were all well-received by Chinese readers, as were the works of Upton Sinclair, Jack London, Nathaniel Hawthorne and John Galsworthy from across the Pacific. The Shi Jie Wen Ku, or Treasures of World Literature (first volume in 1935), was a first in China's publication history. It was edited by Zheng Zhenduo, and the editorial board listed more than 100 writers and translators. Their plan was to publish some 400 world-famous works, and the monumental collection they achieved contributed significantly to China's literary movement (Chen Yugang et al. 1989: 282-285). The Commercial Press presented readers with its Wan You Wen Ku, or the Universal Library of Literary Works, which included translations by Lin Shu and many others.

The translation activities of this period had the following characteristics: (1) the members of many of the societies, "being much concerned with the destiny of the nation," paid special attention to introducing works of realism to Chinese readers with the express purpose of introducing them to ideologically positive elements of foreign literature; (2) with this purpose in mind, they took care to select works for translation whose themes would be relevant to China's political and social conditions; (3) by focusing on both translation and creative writings, they helped promote the New Culture Movement; and (4) groups of expert translators assembled and matured in the process of introducing foreign literature to China (see Chen Yugang et al. 1989: 101-102).

\section{Reform of the Drama}

Like their contemporary prose translators who were introducing Western fiction to China, budding dramatists were enthusiastic about bringing Western plays to the Chinese stage. However, the first play was staged not by professionals but by amateurs, not in China but in Japan, and not from a ready-made scenario but from an adaptation of Lin Shu's translation of Uncle Tom's Cabin. The script was adapted by a Chinese student in Japan named Li Shutong (1880-1942), who later chose to become a Buddhist monk in 1918. The play was put on by members of the Chun Liu (Spring Willow) Drama Society in January 1907 for a Tokyo audience. This D rama Society (disbanded in 1915), the first of its kind in China, had a repertoire that included La dame aux camélias, Uncle Tom's Cabin, Joan Haste, Salomé, etc., all of which were very popular novels at the time. In September of 1907 the Chun Yang (Spring Sun) Drama Society staged Uncle Tom's Cabin in the Lanxin Theatre in Shanghai. In 1908, Ren Tianzhi, a member of Chun Liu Drama Society, joined the Chun Yang D rama Society which, under his direction, offered the Shanghai audience 
a new play: Joan Haste (Ge Yihong 1997: 18). Unlike the earlier huaju, their performance marked a complete break from traditional theatrical practices.

Modern drama soon caught on in Beijing. Hong Shen (1894-1955), then a freshman of Qinghua (Tsinghua) University, produced his first English drama, called Robin Hood, in 1914; it was acclaimed throughout the campus. Hong went to the United States in 1916 to continue his education, first at Ohio State University and then, in 1919, at Harvard University, where he took Professor George Pierce Baker's "English 47" course in playwriting; he was thus became the first Chinese to study Western performing arts systematically. $\mathrm{H}$ is talent and leadership made him a natural director of drama. His adaptation of Oscar Wilde's Lady Windermere's Fan was an immediate success when it was staged in China, although the plot and characters were changed to suit the tastes of Chinese audiences (GeYihong 1997: 61-66; H aiping Liu 1992: xxxiii). Other young dramatists, like Zhao Taimou and Yu Shangyuan (1897-1970), returned from the United States to set up a Drama Department on the campus of the Beijing Arts Academy. And Xiong Fuxi (1900-1965), who studied drama at Columbia University, returned to China to join the new Drama Department, where he taught many courses pertaining to the dramatic arts. But the Beijing Arts Academy was ordered closed in 1927, as Chiang Kai-shek turned his back on the Communists (Ge Yihong 1997: 69-72).

Before the May 4th Movement, foreign plays put on for Chinese audiences gave only the gist of the story. After that point, complete translations of plays were published and used in productions. From 1917 to 1924, some 170 plays by more than 70 playwrights from 17 countries were translated into Chinese, some of which were then staged. Many established writers began to try their hand at writing scripts for the stage, including Guo M oruo, Yu Dafu, Cheng Fangwu, of the Creation Society, Wang Tongzhao, Ye Shengtao of the Literary Studies Society, and Tian Han (1898-1968), Ding Xilin (1893-1974), Li Jianwu (1906-1982), Xiong Fuxi, who dominated the Chinese theatrical scene for more than half a century, producing a great many plays of diverse dramatic genres (Ge Yihong 1997: 77).

\section{Literary Thought in the Early Period}

Much as fiction was turned into an instrument of propaganda, preparing public opinion for the eventual overthrow of the Qing Dynasty, so were various literary ideas made to serve the purpose of politics. Thus M CD ougall (1971: 147) says of the relationship between realism in literature and national revolution,

Realism in literature was introduced into China as part of the New Culture M ovement, and its ready acceptance was determined mainly by general cultural and social forces. If romanticism was allied to the cause of individual liberation and national revolution, so was realism allied to the cause of social reform.

Most advocates and activists of the N ew Literature M ovement around the time of the May 4th Movement were bilinguists or multi-linguists and could follow literary trends in the West. For instance, Chen Duxiu had an article published in issue 3 of volume 1 of the New Youth $(11,1915)$. "A Talk on the History of Modern European Literature and Arts," introduced Chinese readers to the evolution of European literary thought from classicism to romanticism through to realism and naturalism (Shao 
Bozhou 1993: 60). Modernism, encompassing symbolism, expressionism, neo-romanticism was also introduced to readers.

The introduction of foreign literary thought to China brought about a qualitative change in the literary thought of the Chinese literati. In the early part of the century the results of this literary movement were positive: (1) A new type of intellectual, with democratic ideas, modern scientific knowledge and above all, patriotism came to the fore. (2) With the diffusion of Western culture came Marxism and Scientific Socialism, which injected some vigour into the development of modern literary thought, but at the cost of allowing dogmatism and "leftist" tendencies to sway the thinking of writers and theoreticians. (3) Writers, with their diversified personal backgrounds, political persuasions, and aesthetic tastes, often found themselves locked in controversies that sometimes worked against the healthy growth of the literary movement (Shao Bozhou 1993: 12-14).

Western literature would influence China via two main routes: most of the writers around the time of the $M$ ay 4th M ovement had studied abroad, either in Western countries or in Japan. Both groups were schooled in Western literature, but while the former learned it from the West directly, the latter did so indirectly through Japan (M a Liangchun and Zhang Daming 1995: 18). These different educational experiences were manifest in these writers' literary thought. Lu Xun's "Take-it-ism" reflected an eclectic theoretical stance towards the heritage of world culture- absorb what is good from theWest and discard the rest (Shao Bozhou 1993: 296). The publication of M idnight (1932) was an indication of the maturity of Shen Yanbing's "revolutionary realism," which was distinct from Western realism in its pro-working-class stance (Shao Bozhou 1993: 323-342). Lao She's (1899-1966) apprenticeship in fictionwriting was an interesting experience in itself. While he was in England, he felt impelled to write a novel. At first he thought he would model his work on the classic Chinese story, The Scholars, but then turned to Dickens's Nicholas Nickleby and Pickwick Papers instead. Thus inspired, he wrote Old Zhang's Philosophy (1928) followed by many other stories, and a touch of Dickensonian humour and sarcasm is detectable in almost all his novels (Shao Bozhou 1993: 347-354). Lao She's Xiangzi, the Camel M an, is representative of his critical realist style. In Cao Yu's (1910-1996) plays, traces of I bsen's influence can be detected, and the Sunrise acclaimed Cao's play as a masterpiece of critical realism (Shao Bozhou 1993: 360-373). Ba Jin's (1904- ) early ideology was influenced by a medley of French and Russian philosophies, which found expression in his anarchist and humanitarian realist approach to literary creation (Shao Bozhou 1993: 373-390). Lin Yutang was the first to translate the English word humour into Chinese. His writing became a style of its own, and he was referred to as "a master of humour" (Shao Bozhou 1993: 419-440). Liang Shiqiu took a proromantic stance in the 1920s, but was later influenced by Babbitt's neo-humanism (Shao Bozhou 1993: 442-449).

The proletarian literature of the early period (1921-1927) represented a sophisticated literary phenomenon-still, however, in the initial stages of introducing the Western and Marxist-Leninist literary thoughts that would eventually divide the ranks of China's writers and critics (Shao Bozhou 1993: 207). The 10 years between 1927 and 1937 produced a multiplicity of literary programmes, with the League of Left-wing Writers charting the course for the literary movement (Shao Bozhou 1993: 223-227). However, the "leftist" tendencies latent in the various literary societies of 
the movement often led to conflicting literary formularism and conceptualizations (Shao Bozhou 1993: 240-269).

\section{The League of Left-wing Writers}

The League of Left-wing Writers was formed on M arch 2, 1930, marking an important turn in the history of China's modern literature and literary translation. Until it was suppressed in 1936, the members of the League made notable contributions to the Revolutionary Literature Movement. The KMT government launched repeated military efforts to liquidate the revolutionary forces led by the CPC, and promulgated Articles for the Censorship of Propaganda M aterials in 1929 and a Publication Law in 1930 , in an attempt to crush the revolutionary literary activities by suspending publication activities and persecuting revolutionary writers (Chen Yugang et al. 1989: 224-225). Translators of this period had to use pseudonyms instead of their own names, and use Karl for M arx, M axim for Gorky, pu-luo-lie ta-li-ya (proletarian) for wu-chan-jieji or the non-propertied class, etc. in order to circumvent the censorship of KMT authorities (Chen Yugang et al. 1989: 235). Active in this period were Lu Xun, Qu Qiubai (1899-1935), Feng Xuefeng (1903-1976), Zhou Yang (1908-1989), Xia Yan (1900-1995), Rou Shi (1901-1931), Hu Yepin (1903-1931), Yin Fu (19091931), Dai Wangshu (1905-1950).

In 1929, the KM T held a Conference on Propaganda Work- where it introduced the slogan of "Three-People ism" - which was followed by a number of articles justifying their positions. Nationalist literary thought thus made its entry onto China's literary scene to counteract the growing influence of the League of Left-wing Writers. But their brand of nationalism served only the interests of the ruling class, and therefore ran counter to the demands of the proletariat (Shao Bozhou 1993: 455463). During the eight-year-long War of Resistance Against Japan, China's literary circles argued about the theoretical soundness of two slogans, namely, "the National Defense Literature," a term borrowed by Zhou Yang from the Soviet Union, and "Literature for the M asses in the National Revolutionary War," which was formulated by Feng Xuefeng (1903-1976), Lu Xun, and Hu Feng, (1902-1985) in 1936. However, Xu M aoyong (1910-1977) and Zhou Yang voiced strong opposition to this new slogan, and a heated debate ensued, embroiling all interested writers of the time. In "A Reply to Xu M aoyong and Issues of Anti-Japanese and National United Front," Lu Xun made a clear, objective, and complete appraisal of the country's political, social and literary situation, and explained the relationship between the two slogans. In November 1936, the writers closed ranks and rallied under the standard of the United Front Against Japan, with the CPC at its head (Shao Bozhou 1993: 466-480). In Shanghai, as in other areas that had fallen into the hands of Japan, translators went on with their work in spite of significant obstacles. Xu Chi (1914-1996) founded the Chun Wen Yi (Belles Lettres and Art) magazine, to which Li Jianwu, Bian Zhilin (1910- ), Zhu Wen (1900-?), Zhao Jiabi (1908-1997), Man Tao (1916-1978), Zhou Xuliang (1905-1984) and others all contributed. Other magazines, like Xi Yang Wen Xue (Western Literature, September 1940-June 1941) and Wen Xue Yan Jiu (Literary Studies, October 1939-M ay 1940), though short-lived, each played their part in promoting understanding between China and the rest of the world (Chen Qingsheng 1995: 341). Efforts to promote national salvation, while coping with the war-time 
political situation in which literary works were produced to agitate and inspire the people, were reinforced by the worker-peasant-soldier-centred literary trend of the 1940s. Ai Xiaoming, in her doctoral dissertation, traced the origins of China's leftwing literature to the USSR and Japan, an understandable conclusion considering the international and domestic circumstances of the time (Ai Xiaoming 1991).

Within a short six years, members of the League had translated works of M arxist literary theory as well as the progressive literary works of the Soviet Union and other countries. The introduction of Marxist literary theory to China by the translators of the League laid the theoretical groundwork for the development of the Proletarian literary theories that emerged during the war with Japan.

\section{The League of Left-wing Dramatists}

The League of Left-wing Dramatists was formed in 1930, following the founding of the Chinese Left-wing Writers' League. They produced many plays on themes closely related to the situation then facing China, but the repertoires of these theatrical troupes also included, between 1927 and 1930, Shakespeare's The M erchant of Venice, Wilde's Salomé (1930), Lady Gregory's The Rising of the M oon, Henrik I bsen's G hosts, Molière's Le Tartufe (The Hypocrite), John Galsworthy's Strife, M ichael Gold's Jews without M oney, and other Western works.

In the Soviet Area, Li Bozhao (1911-1985) adaptated a play she had seen in the Soviet Union that revolved around the sufferings of a Negro brother and sister. But she gave it the same Chinese name as that used by Lin Shu to translate Uncle Tom's Cabin, namely, The Story of Black Slaves Crying out for Heaven's M ercy. The Lanshan (Blue Gowns) Theatrical School in Ruijin, Jianxi province was renamed Gorky's Drama School in 1933, and trained acters and playwrights. Some 1,000 students graduated from this school (Ge Yihong 1997: 181-182).

During the eight-year War of Resistance Against Japan (1937-1945), China's dramatists and actors remained active in liberated areas, KM T-ruled areas, and in the so-called "I solated Isles." The China National Association of Theatrical Circles for the War of Resistance Against Japan was formed on 31 December, 1937, in Hankou of Hubei province. Chinese and foreign plays alike were staged during this period, including H amlet, M acbeth, La Dame aux camélias, Topaz, Shuixianhua, and an adaptation of Jane Eyre.

Meanwhile, Hu Shi, in his capacity as Director of the Translation Committee under the Board of Directors of Zhong Hua Fund for Education and Culture, initiated a project to translate Shakespeare's complete works, and invited Wen Yiduo (1899-1946), Liang Shiqiu and a number of others to join the team. Somehow, Liang Shiqiu ended up finishing this gigantic task alone. Zhu Shenghao's translation of Shakespeare's plays (that was short five and a half historical plays) earned admiration for China's translators both at home and abroad. Lin Yutang, Xu Zhimo (1896-1931) and Chen Xiying (1896-1970) also contributed to translating Western works of literature (Chen Yugang et al. 1989: 227).

From the outbreak of the Anti-Japanese War to the founding of the People's Republic of China, literary translation continued on two fronts, some translators worked in the liberated areas of Shaanxi, Gansu and Ningxia, while other translators stayed on in the KMT-ruled areas. In the liberated areas, translation focused on 
works from the USSR, while mostly Western classics were being translated in KMTruled areas. The Catalogue of Publications Available at the Revolutionary Base of the Liberated Areas (1937-1949) lists the translations of Soviet publications, including works of drama, films, and fiction (except two titles of the same work, that is, The Sorrows of Young Wurther, by Goethe and translated by Guo Moruo). Under the subheading of reportage are 48 translation titles, including works by Edgar Snow, Agnes Smedley, Anna Louis Armstrong, and other American correspondents. The publication of Smedley's China's Red Army M arches, and Snow's Red Star over China (Journey to the West was the Chinese title given to avoid censorship) were very favourably received, giving people in the KM T-ruled areas a chance to learn the truth about the Red Army from a Western correspondent. At the same time, people in other countries learned about the true situation in China, and their sympathies turned to the CPC. The Yi Bao (Translation Daily) was openly referred to by residents as the "Communist paper" (Cheng Yugang et al. 1989: 296-298). In the KM T-ruled areas, the Shidai (Times) Press was ostensibly a Russian-owned publishing company, but was actually run by the Shanghai underground revolutionaries. Under this cover, many revolutionary works by Soviet writers were introduced to Chinese readers, who consequently developed even firmer convictions to fight for a new China. Li Jianwu, Fu Lei (1908-1966), Fang Zhong (1902-?), and Feng Yidai (1913-) were active in this period.

During the War of Resistance Against Japan, works by Geoffrey Chaucer, Jane Austen, Charles Dickens, Thomas Hardy, Joseph Conrad, Robert Louis Stevenson, William Thackery, Sir Walter Scott, George Gissing, Arthur Conan Doyle, Mark Twain, Jack London, Theodore Dreiser, Pearl Buck, John Steinbeck, Ernest Hemingway, Magaret Mitchell, Agnes Smedley, Edgar Snow, and others were translated or re-translated, all of them representing either romantic, realist, naturalist, or symbolist schools. Theatrical works by George Bernard Shaw, Oscar Wilde, William Saroyan, and Eugene O'N eill were translated, along with the works of William Shakespeare already mentioned (Shao Bozhou 1993: 519-523).

Since the first staging of Uncle Tom's Cabin back in 1907, Chinese audiences had grown accustomed to watching drama or huaju, as Western and Chinese dramas became common place on the Chinese stage. It is worth noting that stage plays served not only to entertain audiences, but to educate them as well. Thus, unlike Shakespeare's historical plays, which simply re-enacted historical events, Guo Moruo's historical plays, such as Tang Di Zhi Hua, Qu Yuan, were put on to voice objections to the heavy-handed rule of the KMT government. Both actors and audiences found an outlet for venting their pent-up rage (See Lin Zhihao 1980: 805-813). In Shanghai, an Art Theatrical Troupe was organized in 1929, and adopted the slogan of "Proletarian Drama." The staging of Carmen, which was an adaptation of a French novelist's work, angered the KM T authorities with its progressive inclination and was closed down. At a meeting called to discuss the problem, the actors decided to form a Union of Shanghai Theatrical Troupes, which came into being the 1st of August, 1930 (Lin Zhihao 1980: 557-566).

Guo M oruo, Tian Han, Lao She, and Cao Yu stood out as the finest playwrights in contemporary China. In war-time Chunking, an advertisement on January 1st announced the forthcoming drama by Guo Moruo as comparable to Hamlet or O thello. That play was Qu Yuan, an historical play, that ran until January 11th, 1942. 
Xu Chi wrote Guo Moruo, calling his attention to the surprisingly likeness between a scene in Qu Yuan and that of King Lear. However, Guo Moruo denied having read King Lear before writing his historical play, and would admit only that the two works were "parallel" (Guo Moruo 1982: 491-501). Apparently Guo was afraid of being accused of plagiarizing Shakespeare. However, just one year earlier, on the 9th of December 1941, he had written, "I have read some theatrical works by Greek playwrights of tragedies, and Shakespeare and Goethe, naturally, under their influence, I began to try to work on historical plays or epic plays" (Guo M oruo 1982: 327-334). It is unavoidable that a playwright, or any writer for that matter, should occasionally come under the influence of a writer he has read. Tian Han reviewed his works in retrospect as having been affected by the anti-realist tendency of the First World War, falling prey to estheticism and to the ideas of the decadent school while studying and translating Oscar Wilde, Edgar Allen Poe, and Charles Baudelaire (Tian Han 1981: 427-429). Lao She had also read Shakespeare and even once wanted to name his own work New Hamlet. Considering that the two styles were not really alike, he later dropped this whimsical idea and called his work Gui Qu Lai Xi, or Returning to Pastoral Life (Hu Jieqing and Wang Xingzhi 1982: 551-559). Cao Yu began his career as a dramatist when he was a student in Nankai School, where he began his apprenticeship by adapting some foreign plays to be put on by his fellow students. One of the plays he adapted was John Galsworthy's Strife (Cui Guoliang 1993; Chen Baichen and Dong Jian 1996: 34/71).

\section{Talks at the Yan'an Conference on Literature and Art}

Mao Zedong's "Talks at the Yan'an Conference on Literature and Art," delivered in May of 1942, set the key note for new guidelines for literary work. He attempted to adapt $M$ arxist literary advocacy to the concrete conditions of war-time China. The principle, outlined in the "Talks", that writers should gear literary creation to "serve workers, peasants and soldiers" has dominated the Chinese literary scene over the second half of this century. The rationale of the "Talks" was that writers should shift their allegiance to side with the masses and that excessive exposure to dark thoughts would be harmful to the cause of the revolution. Therefore, political criteria should come first in judging the quality of literary creation (Tang Tao and Yan Jiayan 1983: 177-192). This dogmatic and sometimes misconstrued interpretation of the "Talks" dampened the creative enthusiasm of writers and the candidness of critics, and had a negative influence that would be felt in the decades that followed (Tang Tao and Yan Jiayan 1983: 206). The Chinese version of realism during the war was known as revolutionary realism, with Ding Ling (1904-1986), Wang Shiwei (1900-1947), Zhou Yang, and others standing as its proponents and practitioners (Shao Bozhou 1993: 524-539).

The General Catalogue of Publications during the Period of the Republic of China (1911-1949): Foreign Literature collects some 4404 titles, including works of translation of world literature and studies of foreign literature (General Catalogue 1987: x). Among these are 795 translated titles of works by and about British authors and 558 translated titles of works by and about American authors. Together, these 1353 titles make up just under $31 \%$ of the total number of titles in the General Catalogue. These titles cover theories and studies, authors and their works, works of group of authors, 
poetry, drama, fiction (works of both groups of authors and individual authors), prose, reportage, memoirs and diaries, and juvenile literature. Under the heading Individual Works of British Novelists, 68 names are given, with 470 translated titles grouped under them; a further 22 British playwrights are listed with their 144 titles. For individual works by American novelists, 43 names are listed atop 331 titles, along with 10 American playwrights and their 34 titles. We must remember that the number of translated titles does not necessary agree with the actual number of original works translated, for the same original work may have had many renditions. For example, the 470 titles under the subheading of works by individual authors are translations of about 345 works of fiction by British authors, which means that 470$345=125$ titles are just duplicate versions. Daniel Defoe's Robinson Crusoe and Jonathan Swift's Gulliver's Travels have 12 translations each, including abridged, condensed or adapted versions. Similarly, the 331 titles under the subheading of works by individual authors are translations of about 230 works of fiction by American authors, which means that $331-230=101$ titles are just duplicate versions. And L.M. Alcott's Little Women and Good Wives, and Pearl S. Buck's The Good Earth each had seven versions.

\section{9-1978}

\section{The New Wave Thwarted}

The long-awaited new wave of translation after four decades of war and the founding of the People's Republic would take another three decades to arrive. During the intervening years, one political campaign after another unfolded on a nation-wide scale, throwing people into the malestrom of politics, and leaving them alternately excited, baffled and disappointed. Condemnation was followed by rehabilitation; accusations of being feudalistic, bourgeois, and revisionistic were then re-judged and erased. Shen Yanbing's talk at the Second National Conference on Literature and Arts (September 1953) would have been the start signal for renewed nation-wide efforts to translate works of foreign authors had it not been for the frequent interruptions of political campaigns that would throw the translators off-balance once again. $M$ any of the projects conceived by Dong Qiusi (1899-1969) did not materialize until the 1980s. ${ }^{6}$ The leftist turn in the literary movement affected translation on a national scale. Translators became recreant, cautious in their selection of books for translation; they would skip sensitive paragraphs, and often insert a few lines warning readers about possible evil influences- these lines were really meant more as talisman to the translator than counsel to readers. In the first year of the Cultural Revolution, teachers and students in foreign language schools busily criticized Western authors. Shelley's "O de to the West Wind" was a favourite object of criticism, for only the "East Wind" was to be extolled in those years." Between 1966 and 1976, translation of literary works from the West virtually ceased. O ccasionally, Soviet novels were sanctioned for translation for "internal reference."

In the 17 years after 1949, some 100 works by British authors and 50 works by American authors had been translated or re-translated by veteran translators, some of whom were professional freelance translators. The quality of translation in this period was much better than in the pre-liberation days (Chen Yugang et al. 1989: 
371). In 1951, the First Conference on Translation Work was convened, followed by the National Conference on Literary Translation in 1954. Translation in this period was directly supervised by the CPC Department of Publicity. Greater emphasis was placed on introducing Soviet and Eastern European literary works, at the expense of many excellent works from the West (Chen Yugang et al. 1989: 350-352).

\section{9-NOW}

\section{Thawing}

Two and a half years after the downfall of the Gang of Four, Dushu (Reading) M agazine published its first issue in April, 1979. Li Honglin, a literary critic, said in his article "No Forbidden Areas for the Readers," that during the 10 years of the Cultural Revolution, "almost all libraries had become prisons for books, there were only a few books which readers were allowed to read. Books of and about Confucius through Dr. Sun Yat-sen, Shakespeare through Tolstoy had all been kept prisoners" (see D ushu 1979 1: 2-7). The cultural dictatorship had deprived readers of the freedom to read hundreds of thousands of books that were part of mankind's cultural heritage. The long queues to buy Chinese and foreign classics in that late spring of 1978 were proof that people need "spiritual food" to nourish their souls. The Beijing-based World Literature, the only magazine to carry works of translation, recommenced publication. Yi Lin, or Translations, had its first issue on the bookstands by late 1980. Translators who had been dormant for 10 years took up their work with renewed zest. All these signs go to show that Chinese readers need foreign literature to learn about how other peoples live and work, that Chinese writers need foreign works to give them inspiration and enrich their techniques and expressions. Renato Poggioli speaks candidly of the need to translate foreign works to inject vigour into the national literature,

Especially in modern times, a national literature reveals its power of renewal and revival through the quality and number of its translators. Sometimes it is able to survive only because of their efforts. We know all too well that a culture survives only by a proper response to the challenge of change, and by its timely refusal to go on aping itself. (Poggioli, "The Added Artificers," in Brower 1959; see M cD ougall 1971: 268)

Prior to the mid-1970s, and back to the turn of the century, Chinese writers of fiction and drama had been influenced by the realist school of Western literature. Modernism, which had been barred from China since 1949, returned with redoubled impact on Chinese writers when China opened its doors to the outside world again in the early 1980s. Capitalizing on the forms and techniques of modernist writing, Wang M eng (1934- ), Zong Pu (1928- ), Shen Rong (1936- ), Zhang Xinxin (1953- ), Tie Ning (1958- ), Mo Yan (1957- ), Liu Suola (1955- ), Han Shaogong (1953- ), Wang Anyi (1954- ) and others wrote novels, novellas, short stories and tales that bedazzled Chinese readers. Such literary concepts as stream of consciousness, drama (fiction) of the absurd, black humour, imagism, psychoanalysis, impressionism, futurism, the beat generation, the angry young men, and so on, opened readers' eyes to the ever-changing panorama of literary creation (see Feng Mu et al. 1987: 197-234). The absurd, magic, symbolic, obscure, stream-of-consciousness techniques these authors employed in their experiments were tolerantly accepted, if not appreciated, by 
critics, and received by readers with curiosity and knowing, sometimes bitter, smiles. One recently published collection has gathered these authors into one volume, entitled A Compendium of Chinese Black Humour Stories (see Zheng Ronghua 1996). Wang Meng, in his capacity of M inister of Culture in the late 1980s, once called on writers to equip themselves with new learning, to become scholarly-type writers. This seemed a tall order to many. For one thing, they would have to spend a lot more time and energy studying new concepts and theories, such the American new criticism, phenomenology, hermeneutics, semiotics, formalism, post-structuralism, reception theory, post-modernism, and so on (see Terry Eagleton 1988). For Chinese writers to become acquainted with these disciplines and genres, translators would have to do more than translate literary works. Indeed, translators would have to become scholarly-type translators themselves.

In the initial post-liberation years, when China was still on friendly terms with the Soviet Union, some 50 Soviet plays were staged in China. In 1954, commemorating Shakespeare's 390th anniversary, Hamlet and Romeo and Juliet were performed; commemorative events were also held in 1964 for Shakespeare's 400th anniversary. But soon after, Western drama disappeared from theatres across the country as the political storm drew near.

China's policy of openness that began in the late 1970s and early 1980s brought Western dramas back to the Chinese stage in even greater number. Trained in the Brecht and Stanislavsky tradition, contemporary Chinese actors began to break away from the limits of the stage and exploit the "alienation effect," which proved to be an immediate success. The Death of a Salesman, directed by Arthur M iller himself, provided much food for thought to Chinese audiences, as did The Fence, a Broadway hit, in 1996. Chinese audiences are close to the Western stage, just as China is close to the rest of the world.

The impact of translated literature on the development of Chinese literature was far-reaching: it broadened the field of vision of China's writers, providing them with up-to-date information about the state of world literature in general and British and American literature in particular. Various literary thoughts and trends were studied, and literary techniques experimented, by Chinese writers. The traditional fixedformat manner of writing fiction, the zhanghui style, gave way to new modes of composition. In his survey of the narrative patterns of Chinese fiction, Chen Pingyuan observed the shift of narrative patterns in Chinese fiction under the influence of Western fiction in three aspects, namely, the shift of patterns in the temporal sequence of narration (1988: 37-64), the shift in narrative voice (1988: 65-105) and in structure of narration (1988: 106-144). New expressions were assimilated into the Chinese language, enriching both its syntax and vocabulary, despite initially vehement objections. Above all, the importation of Western literature into China had helped shape the ideology of the Chinese intellectual community. Many of the famous men of letters in China's modern history began to learn foreign languages and practice translating after having been exposed to works of translation. In the process, their modes of thinking began to change, they perceived the world from new angles, and found themselves caught in the clashes between the East and West. 


\section{The Publishing World}

As recent statistics on the publication of translated works are not available, we will have to rely on a quick tour of the book markets. We will leave aside the classics which have already been mentioned above, and look only for those books which translators are translating at the speed of light for publishers who are vying with each other for copyright. Coming into view are the detective fiction of Agatha Christie, Dashiell Hammett, the spy stories of John le Carré, Ken Follet, the thrillers of Ian Fleming, Patrick Alexander, the war stories of M. Powell, R. M oss, Jack Higgins, Graham Greene, Herman Wouk, the murder stories of Frederich Forsyth, the family stories of John Gardner, Frank O'H ara, the social fiction of C. P. Snow, John Cheever, John Updike, Eudora Welty, the parables of William Faulkner, the sagas of Isaac Singer, the marriage stories of Norman Mailer, Paula Fox, the family legend of Alex Haley, the sci-fi of Arthur C. Clarke, etc. (see Evans 1976; Danniel H offman 1979). The Chinese-American literature which is now part of the ethnic literature of the United States is fast being introduced to readers in their ancestral land. The Chinamen and The Woman Warrior by M axineH ong Kingston (汤亨亭), The Joy Luck Club, and The Kitchen God's Wife by Amy Tan (谭恩美), the Thousand Pieces of Gold by Ruthanne Lum McCunn (林露德) are already well-known to some Chinese readers. $M$ any of the works of Han Suyin ( 韩素音), a British-Chinese writer, are also familiar to Chinese readers. The books of translation we find in the markets form just the tip of the iceberg of the great body of literary work that has been published so far in the USA and the UK.

At the Beijing Book Order Fair of 1997, publishers gathered in a crowded hall, displaying a kaleidoscopic array of books- biographies of leaders, celebrities, entrepreneurs, financiers, statesmen, war-mongers, ruffians, courtesans, emperors and empresses, princes and princesses, computer wizards; books telling readers the secrets to getting rich, teaching them to use computers and repair cars, to slim their bodies; books of popular science, dictionaries of all sizes, hashed and rehashed, etc. Beijing University Press got an order for 100,000 copies of Microsoft Secrets, PLA Literature and Arts Press received an order for 10,000 copies of My American Journey, and The Celestine Prophecy: An Adventure, $\mathrm{H}$ ebei Education Press bought the copyright for the Chinese translation of Kafka's works, and so on and so forth (Ji M engxin, "Book Markets: Beijing Book Order Fair '97," in Zhonghua Reading Weekly, 5 February, 1997). The China Social Sciences Press plans to publish Self-selected Works by Western Critics, the Shanghai Sanlian Press will put out a 20th Century Thinkers Series, Hebei Education Press has al ready accomplished its great project of Western Literary Giants Series, the Shanghai Far-East Press will release 20th Century Worlds Cultural Celebrities, all 10 volumes at once (Huyan Hua, "Academic Works of Western Authors: A Summing Up," in Zhonghua Reading Weekly, 29 January, 1997).

Since 1990, the Shanghai Translation Press has published 26 world famous works, and has sold 16 million books, including 1.46 million copies of Jane Eyre, 1 million copies of Pride and Prejudice; at 100,000 copies, Ivanhoe was a poor seller. Why is demand for these books so hot? Many people, especially the young and middle-aged, buy them not to read but to decorate their rooms. Elderly people do not buy them, because they have read them; teenagers do not buy them, because they are bogged down with their lessons. Institutional and corporate purchasing is another 
strange phenomenon in recent years. Government departments or enterprises will buy these world famous books in deluxe editions and then give them to their employees as bonuses to be placed inside their glassed bookshelves. Because the publishers are busy putting out the classics, the excellent works by contemporary authors are often deprived of the opportunity to go to the press (Lin Xinhua, "Famous Works Are Hot Cakes: Glad or Sad?" in Zhonghua Reading Weekly, 9 A pril, 1997). It is impossible to know how long this situation will last, but one thing we are sure of is that translation will go on, and translators will always have work to do. What we need, however, are really good translators and really good translations.

\section{NOTES}

1. Thomas Percy's version was published in London in 1761, under the title Hau Kiou Choaan or the Pleasing History, A Translation from the Chinese Language. J. F. Davis' version came out in 1829 under the title The Fortunate Union, A Romance, Translation from the Original. The titles of other abridged translations are A Matrimonial Fraud, by R. K. Douglas in 1883, The Breeze in the Moonlight: The Second Book of Genius in 1926, etc. There are about 30 versions of this Chinese novel, according to Wang Lina, 1988: 313-323.

2. The translation of the Holy Bible was done by Robert M orrison (1782-1834), a missionary from England, between 1808-1819, and was published in 1823 .

3. According to a very thoroughgoing survey by a group of Japanese scholars, the number of fictional works published between 1840-1911 reached a total of 2304 titles, more than twice as much as Ah Ying's statistics; among these 1288 were creative works and 1015 were translations, thus overruling Ah Ying's assertion that during that period translations outnumbered creative works. See Zhou Zhenhe, "How Many Fictional Works Were Published during the Late Qing Dynasty?", in Wen Hui Readers' Weekly, Page 4, January 10, 1998.

4. The asterisked proper names for these newspapers or magazines are my translation.

5. Wang Shifu, a dramatist of the Yuan Dynasty, was, from the works he wrote, believed to be active between 1295-1308.

6. See Shouyi Fan, "Highlights of Translation Studies in China Since Mid-Nineteenth Century."

7. In the first and second editions of Fang Zhong's translation of the "General Prologue to Canterbury Tales," Fang even turned "Zephyr" into "dong feng" (East Wind) to go along with the prevailing "political wind" of the time; however, in a later edition (1983), he changed it into "he feng" (gentle wind, breeze). See Note 1, p. 3 in Fang 1955 or Note 1, p. 333 in Fang 1979.

\section{REFERENCES}

Ah, Ying (Qian Defu; another penname, Qian Xingcun) (1957): A Bibliographical Survey of D rama and Fiction in the Late Q ing Dynasty, Shanghai, Shanghai Classic Literature Press.

Ai, Xiaoming (1991): Exploring the Origin of China's Left-wing Literature, Changsha, Hunan Literature and Arts Press.

Brower, R. A. (Ed.) (1959): On Translation, Cambridge (Mass.), Harvard University Press.

Chen, Baichen and Jian Dong (1996): A History of Drama in Modern China, Beijing, Chinese Drama Press.

Ch en, Pingyuan (1988): The Shift of Narrative Patterns of Chinese Fiction, Shanghai, Shanghai People's Press.

Ch en, Qingsheng (1995): The Shanghai Literature During the Period of War of Resistance Against Japan, Shanghai, Shanghai People's Publishing Co.

Ch en, Yugang et al. (1989): A History of China's Translated Literature, Beijing, The China Translation and Publishing Company.

Chinese Department of Nankai University (1979): A Short History of Chinese Fiction, Beijing, People's Literature Publishing House.

Cui, Guoliang (1993): The Translated and Adapted Plays by Cao Yu in His Earlier Career, Shenyang, Liaoning University Press. 
Davis, A. R. (Ed.) (1962): Penguin Book of Chinese Verse, Penguin, Harmondsworth.

Eagl et on, Terry (1988): Literary Theory: An Introduction, Chinese edition translated by Wang Fengzhen, Beijing, China Social Sciences Press.

Evans, Ifor (1976): A Short History of English Literature, Harmondsworth (Middlesex), Penguin Books Ltd.

Fang, Zhong (tr.) (1955): Geoffrey Chaucer's Canterbury Tales, Shanghai, Xin Wenyi Press.

- - (1979): Collected Works of Geoffrey Chaucer 2, Shanghai, Shanghai Yiwen Press.

- - (1983): Geoffrey Chaucer's Canterbury Tales, Shanghai, Shanghai Yiwen Press.

Feng, Mu et al. (Eds) (1987): Modern Philosophical and Literary Thoughts of the West, Shanghai, Shanghai Literature and Arts Press.

Gao, Wensheng (1990): A H istory of Dramatic Literature of Contemporary China, Nanning, Guangxi People's Press.

Ge, Yihong (Ed.) (1997): A General History of Chinese Huaju Drama, Beijing, Culture and Arts Press.

Guang M ing Daily and China Publishers Association (1997): Zhonghua Reading Weekly, January to May.

Guo, Moruo (1982): Guo M oruo's Complete Theatrical Works, vol. 1, Beijing, Chinese Drama Press.

Gu o, Yanli (1991-1993): A History of the Development of Literature in M odern China, Books 1-3, Jinan, Shandong Education Press.

H of $f$ man, Daniel (1979): H arvard Guide to Contemporary American Writing, Harvard University Press.

H u, Jieging and Xingzhi Wang (Eds) (1982): Lao She's Complete Theatrical Works, Beijing, Chinese Drama Press.

H u, Shi (1917): "A Constructive Theory on Literary Revolution", N ew Youth, no. 1, volume 4.

Kang, Youwei (1956): Da Tong Shu, Beijing, The Classics Publishing House.

- - (1958): Kang Youwei's Poems and Essays, Beijing, People's Literature Press.

- - (1985): Kang Nan H ai Xian Shen Kou Shuo, Guangzhou, Sun Yat-sen University Press.

Kong, Li (1962): Lin Shu and Novels Translated by Lin Shu, Beijing, Zhonghua Bookstore Press.

Li, Huang (1973): Reminiscences, (Xue Dun Shi Hui Yi Lu), Taiwan Zhuan Ji Wen Xue Publisher.

Liang, Qichao (1921): "The Impact of Translated Literature on Literary Writing," excerpt from "Translation in Ancient China," Reform, No. 11, Volume 3.

Lin, Zhihao (Ed.) (1980): A History of M odern Chinese Literature, Beijing, Chinese People's University Press.

Liu, Haiping and Lowell Swortzel I (Eds) (1992): Eugene O'Neill in China: An International Centenary Celebration, New York, Greenwood Press.

Liu, Shide (Ed.) (1993): An Encyclopedia of Fiction in Ancient China, Beijing, China Encyclopedia Press.

Lu o, Xinzhang (Ed.) (1984): Essays on Translation, Beijing, Commercial Press.

M a, Liangchun and Daming Zh ang (Ed.) (1995): History of M odern Literary Thoughts in China, Beijing, October Wenyi Press.

M a, Zuyi (1984): A Short H istory of China's Translation - Prior to the M ay 4th M ovement, Beijing, China Translation and Publication Company.

M cD ougal I , Bonnie S. (1971): The Introduction of Western Literary Theories into M odern China (1919-1925), Tokyo, The Centre for East Asian Cultural Studies.

M 0, Shuyi (1994): Drama, Beijing, People's Literature Press.

Ren, Fangqiu (Ed.) (1988): A History of M odern Chinese Literature, Kaifeng, Henan University Press.

Research Institute of Huaju Drama of Chinese Arts Research Academy (Ed.) (1987): Collection of Historical Materials Relevant to Chinese Huaju D rama, vol. 1, Beijing, Culture and Arts Press.

Rul and, Richard and Malcolm Br ad bur y (1991): From Puritanism to Postmodernism-A History of American Literature, London, Routledge. 
Sh ao, Bozhou (1993): A Study of China's M odern Literary Thoughts, Shanghai, Xue Lin Press. Sh i, Changyu (1994): Evolution of China's Fiction, Beijing, Sanlian Press.

Sh i, Jianye (1993): Dispersion of Chinese Literature in the World and Its Impact, Jinan, The Yellow River Press.

Song, Bainian (Ed.) (1994): Chinese Classic Literature Abroad, Beijing, Beijing Languages Institute Press.

Tan, Chuliang (1996): A Historical Study of China's M odern School Literature, Shanghai, Xue Lin Press.

Tang, Tao and Jiayan Yan (1983): A H istory of M odern Chinese Literature, (III) Beijing, People's Literature Press.

Tian, H an (1981): Selected Theatrical Works of Tian Han, Beijing, People's Literature Press.

The Library of the Chinese People's University (Ed.) (1989): The Catalogue of Publications Available at the Revolutionary Base of the Liberated Areas, Beijing, Chinese People's University Press.

The National Library of China (1987): General Catalogue of Publications During the Period of the Republic of China (1911-1949): Foreign Literature, Beijing, Bibliography and Documentary Literature Press.

Wang, Lina (1988): Chinese Masterpieces Abroad: Classic Fiction and Drama, Shanghai, Xuelin Press.

Wang, Zhiwu (1988): A Dictionary of Ancient Dramatic Pieces for Appreciation (Yuan Dynasty Productions), Xi'an, Shaanxi People's Press.

Wu, Zhongjie (1996): History of M odern Literary Thoughts of China, Shanghai, Fudan University Press.

Xue, Suizhi and Juncai Zh ang (1982): Sources for Lin Shu Studies, Fuzhou, Fujian People's Literature Press.

Xia, Xiaohong (Ed.) (1992): Selected Essays of Liang Q ichao, Volumes $1 \& 2$, Beijing, China Radio and Television Press.

Xiong, Yuezhi (1994): The Dissemination of Western Learning and the Late Qing Society, Shanghai, Shanghai People's Press.

Zhang, Geng and Hancheng Guo (Eds) (1980): General History of Chinese Drama, (I) Beijing, Chinese Drama Press.

Zh ang, Hong (1992): Chinese Literature in Britain, Guangzhou, Huachen Press.

Zh eng, Ronghua (Ed.) (1996): A Compendium of ChineseBlack Humour Stories, Beijing, The Qun Yan Press.

Zhu, Defa (1986): A History of Literature of May 4th Movement in China, Jinan, Shandong Literature and Arts Press.

Zou, Zhenhuan (1996): 100 Works of Translation that Have Influenced the Society of Modern China, Beijing, The China Translation and Publishing Company. 